\title{
A Comparison of the Shading Effectiveness of Five Different Street Tree Species in Manchester, UK
}

\author{
David Armson, Mohammad Asrafur Rahman, and Anthony Roland Ennos
}

\begin{abstract}
One major benefit of urban trees is the shade they provide on sunny days; this reduces the heat stored in engineered surfaces and lowers the heat load on people, increasing their comfort. This study compared the shading effectiveness of five small street tree species within the urban landscape of Manchester, UK. The area of shade produced by each tree during early and midsummer 2012 was calculated from morphological measurements, such as canopy height, width, and aspect ratio. The effect of tree shade on air, mean radiant and surface temperatures was also compared and related to the leaf area index (LAI) of the canopy. It was found that tree shade reduced mean radiant temperatures by an average of $4^{\circ} \mathrm{C}$, though neither tree species nor LAI had a significant effect. Tree shade reduced surface temperatures by an average of $12^{\circ} \mathrm{C}$, and the tree species and LAI both had significant effects. Tree species with higher LAI, Crataegus laevigata and Pyrus calleryana, provided significantly more cooling than the other species, and surface temperature reduction was positively correlated with LAI. This study has shown that trees are useful in improving both human thermal comfort and reducing surface temperatures in urban areas, and that selection of tree species with high LAI can maximize the benefits they provide.

Key Words. England; Human Thermal Comfort; Manchester; Mean Radiant Temperature; Surface Temperature; Tree Shade; United Kingdom; Urban Heat.
\end{abstract}

Trees provide two major benefits to the urban climate. First, like other forms of vegetation, the leaves intercept sunlight and much of its energy; the heat is used for transpiration. As a consequence, the leaves and the surrounding air are cooled compared to areas covered with built surfaces (Pauleit and Duhme 2000; Leuzinger et al. 2010). Leaf temperatures have been measured as being $11^{\circ} \mathrm{C}-30^{\circ} \mathrm{C}$ cooler (Pauleit and Duhme 2000; Leuzinger et al. 2010) than surrounding built surfaces, the effect being greatest at midday during hot sunny weather, and greater in trees than green roofs or grass. However, the effects on air temperature tend to be small; for example, parks are only $1^{\circ} \mathrm{C}$ cooler on average (Bowler et al. 2010) than the surrounding areas, partly because of the poor coupling between surfaces and air, and because warm air is readily advected into them (Oke 1978; Bowler et al. 2010). A better way of quantifying the cooling benefits of vegetation is to measure the rate of evapotranspiration, which in trees can be performed by measuring weight loss (Miller 1980; Kjelgren and Montague 1998) of containerized trees, using porometry (Rahman et al. 2011), or in recent years by using sap flow gauges (Pataki et al. 2011; Peters et al. 2011).

The second benefit of trees is that they also provide shade because of their elevated and extensive canopies. This reduces the receipt of solar radiation beneath the tree; the effect is maximized in the summer when deciduous trees are in leaf and solar radiation can be reduced by up to $90 \%$ in tree shade (Heisler 1986a). This is important for two reasons: The first reason is that tree shade helps people to cool down because it is the radiation exchange between a person and the surrounding local environment, not convective transfer, that most affects a person's thermal comfort, as quantified by measures such as their perceived or physiologically equivalent temperature (PET) (Matzarakis et al. 2007). As a result, a person in the shade feels cooler than a person in the sun (Monteith and Unsworth 1990). Measuring PET accurately is a complex procedure as it is affected by several factors, including the surface temperature of surrounding areas, air temperature, and wind speed. However, it has been found that globe thermometers provide a good indication of the mean radiant temperature around a person (Thorsson et al. 2007), so using globe thermometers in and out of tree shade can offer a good indication of how it affects human thermal comfort. In a previous study, the authors have shown that constant tree shade can reduce mean radiant temperatures by $5^{\circ} \mathrm{C}$ $7^{\circ} \mathrm{C}$ in the summer in Manchester, UK (Armson et al. 2012).

The second major benefit of tree shade is that it can reduce the amount of heat gained by the surface in shade, furthering the cooling effect that trees provide. Many studies have shown that tree-shaded areas of built surface can be much cooler than those in the sun (Akbari et al. 1997; Scott et al. 1999; Akbari et al. 2001; Streiling and Matzarakis 2003; Wong et al. 2003), though the effect is somewhat smaller than the completely dense shade cast by buildings. In Manchester, UK, it was found that concrete surfaces shaded permanently by a bank of trees can be cooled by up to $20^{\circ} \mathrm{C}$ in the summer (Armson et al. 2012). Shaded built surfaces can be almost as cool as surfaces covered by evapotranspiring grass (Armson et al. 2012). Trees have the added advantage over grass swards, moreover, that they provide surface cooling while retaining most of the resilient built surface; the planting pit is generally much smaller than their canopy, and the shade the canopy provides is cast over a greater surface area than the canopy area, because the zenith angle of the sun is generally below 90 degrees. 
Although street trees should be particularly effective at providing cooling benefits, the effectiveness of different species is likely to differ. In general, more drought-tolerant and slow-growing trees have less dense canopies, and so reduce radiation less than faster-growing species (Heisler 1986a; Heisler 1986b; Shashua-Bar and Hoffman 2000), as well as providing less evapotranspirational cooling. However, surprisingly little work has been done to compare the amount and depth of shade cast by individual street tree species and their likely effects on the cooling of people and the surfaces beneath them. Perhaps this is because it is harder to measure light levels meaningfully beneath isolated trees than beneath a continuous forest canopy. Of course, light levels beneath street trees also depend on how they have been managed and whether they have been pruned.

A wide range of species are grown in cities across central and northwestern Europe, but the European tree survey has shown that three to five genera account for $50 \%$ to $70 \%$ of all street trees planted (Pauleit 2003). In England, UK, a survey of urban street trees showed that six species account for $37 \%$ of all trees and shrubs planted within cities (Britt and Johnston 2008). The main six species were Leyland cypress (× Cupressocyparis Leylandii), hawthorn (Crataegus spp.), sycamore (Acer pseudoplatanus), silver birch (Betula pendula), common ash (Fraxinus excelsior), and privet (Ligustrum spp.). Increasingly, smaller tree species are being planted as street trees because they fit better into narrow pavements and are easier to manage (Britt and Johnston 2008). Particularly common genera are members of the family Rosaceae, namely Pyrus, Prunus, Crateagus, Malus, and Sorbus. Therefore, understanding the shading effects of these small tree species is critical in maximizing the climatic benefits of street trees.

This study was designed to compare the shading benefits of five commonly planted street trees in Manchester, UK, and to investigate how differences in their canopy characteristics might affect their performance. To do this, the size and canopy shape of trees of each species were measured, along with their leaf area index (LAI), and the air, mean radiant, and surface temperatures were measured both in the sun and in the shade beneath them. The aim was that this study would give a broad comparison of the climatic benefits of the five species, and indicate what factors make for a good street tree. This study was conducted in Manchester because it is a good example of a temperate city with a maritime climate and a pronounced heat island effect of $3^{\circ} \mathrm{C}-5^{\circ} \mathrm{C}$ (Smith et al. 2011) and it allowed us to compare the effects of short-term shade provided by street trees with those of permanent deep tree shade (Armson et al. 2012) measured in the same city.

\section{MATERIALS AND METHODS}

\section{Location and Selection of Sample Trees}

Investigations into the benefits of urban street trees were conducted on five tree species in six residential locations within southern Manchester, UK. These trees were sampled twice during the summer of 2011, between 11:30 am and 4:30 pm, when temperatures were near their maximum, on clear warm days. Because of the large sample size and the poor summer weather conditions, sampling could not be carried out over a single day; days often clouded over after a sunny morning before all the trees could be monitored. Therefore the trees were measured over two days in early summer, on May 25 and June 3 (referred to as early summer) and over three days during July 14, 15, and 25 (referred to as mid-summer). During these days, mean maximum temperatures were around $22^{\circ} \mathrm{C}$, similar to the "average" days for summers 2009 and 2010 (Armson et al. 2012), but this was largely because there was no heat wave during the poor summer; temperatures were low during the preceding days. Nevertheless, the periods of measurement were sunny, with peak short wave radiation of around $800 \mathrm{~W} \mathrm{~m}^{-2}$, meaning the cooling effects of the tree shade should have been close to the maximum possible.

In total, 51 trees were examined; of which twelve were Crataegus laevigata, ten Sorbus arnoldiana, ten Prunus 'Umineko', ten Pyrus calleryana and nine Malus 'Rudolph'. The trees were distributed over six locations: twenty

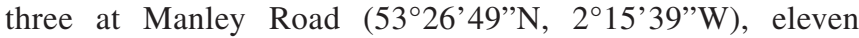
at Cringle Road $\left(53^{\circ} 26^{\prime} 10^{\prime \prime} \mathrm{N}, 2^{\circ} 10^{\prime} 53^{\prime \prime} \mathrm{W}\right)$, eight at Victoria Road $\left(53^{\circ} 27^{\prime} 05^{\prime \prime} \mathrm{N}, 2^{\circ} 15^{\prime} 33^{\prime \prime} \mathrm{W}\right)$, three at Granville Avenue $\left(53^{\circ} 26^{\prime} 50^{\prime \prime} \mathrm{N}, \quad 2^{\circ} 15^{\prime} 55^{\prime \prime} \mathrm{W}\right)$, five at Thorncliffe Grove $\left(53^{\circ} 26^{\prime} 36^{\prime \prime} \mathrm{N}, 2^{\circ} 10^{\prime} 51^{\prime \prime} \mathrm{W}\right)$, and one at Beech Range $\left(53^{\circ} 26^{\prime} 37^{\prime \prime} \mathrm{N}, 2^{\circ} 11^{\prime} 49^{\prime \prime} \mathrm{W}\right)$ (see Table 1 for species distribution). The sites were all of similar morphology, being composed of rows of terraced houses, with a road width of $4.5 \mathrm{~m}$ to $7 \mathrm{~m}$, and paved with dark asphalt. The selected trees had been planted in 2005-2006 at an age of 4-5 years, and were planted in the same rooting conditions, each tree being in a 1.5 $\mathrm{m}^{2}$ open tree pit located along the curb edge of the pavement. All trees were planted a minimum of two meters away from any buildings, were seven to ten meters apart from each other, were free of damage, dieback, and visible disease and were in areas that were free from shadow from dawn till 4:30 pm.

\section{Morphological Measurements}

At each of the sample trees, a standard set of morphological measurements were taken. Tree canopy spread and bole height were measured using a standard tape measure. East and

Table 1. The distribution of C. laevigata $(n=12)$, S. arnoldiana $(n=10)$, Prunus 'Umineko' $(n=10), P$. calleryana $(n=10)$, and Malus 'Rudolph' ( $n=9)$ over the six sample locations in Manchester, UK.

\begin{tabular}{|c|c|c|c|c|c|c|}
\hline \multirow[t]{2}{*}{ Street } & \multicolumn{6}{|c|}{ Distribution of tree species over the sample area } \\
\hline & C. laevigata & S. arnoldiana & Prunus 'Umineko' & P. calleryana & Malus 'Rudolph' & Total number of trees \\
\hline Manley Road & 1 & 6 & 10 & 6 & 0 & 23 \\
\hline Cringle Road & 4 & 4 & 0 & 0 & 3 & 11 \\
\hline Granville Avenue & 3 & 0 & 0 & 0 & 0 & 3 \\
\hline Thorncliffe Grove & 0 & 0 & 0 & 0 & 5 & 5 \\
\hline Beech Range & 0 & 0 & 0 & 0 & 1 & 1 \\
\hline
\end{tabular}


West canopy spread was particularly important, as this would have the greatest effect upon the width of the shade during the sample period when the sun was south of the sample trees. Total tree height was measured using a Suunto Clinometer and total canopy height and area were calculated from these measurements. LAI was recorded using an AccuPAR model LP-80 PAR/LAI Ceptometer (Decagon Devices, Washington, U.S.).

\section{Shade Area Analysis}

In order to assess the impact of each tree on the local environment, it was first necessary to calculate the amount of shade it produced. It was not possible to directly measure this, due to time constraints and because the busy roads restricted access. Therefore, the area of shade was calculated using the morphological measurements.

Total shade area produced by each of the sample trees was calculated using Monteith and Unsworth's (1990) equation for shade area produced by an ellipsoidal canopy, using the angle of the sun at each sample time.

$$
A_{h}=\pi b^{2}\left\{1+\frac{\mathrm{a}^{2}}{\mathrm{~b}^{2} \tan ^{2} \beta}\right\}^{0} .5
$$

where $\mathrm{a}$ is the vertical canopy radius, $\mathrm{b}$ is the horizontal canopy radius, and $\beta$ is the angle of the sun to the horizontal. During the sample periods in early summer the sun angle at midday was between 57.4 and 58.7 degrees, and in mid-summer between 56.2 and 58.2 degrees.

To assess if the shape of the canopy had any effect upon the shade area produced or the temperatures below the canopy, aspect ratio was also calculated from the morphological results:

$$
a_{r}=\frac{a}{b}
$$

\section{Air Temperature}

At each of the sample trees, two air temperature readings were taken at a height of $1.1 \mathrm{~m}$ using a Digitron 2084T platinum resistance thermometer with a PT100 air probe and radiation shield attached. The first reading was taken five meters east of the center of the shade cast by the tree canopy, ensuring that the air temperature probe was at least two meters away from the edge of the shade area. The second reading was taken with the temperature probe located within the center of the tree shade. Both readings had an acclimation period of two minutes before the reading was taken, increasing the accuracy of the result.

\section{Mean Radiant Temperatures}

At each of the tree sample locations, two mean radiant temperature readings were taken at a height of $1.1 \mathrm{~m}$ using a HOBO U30 data logger with two globe thermometers attached. The globe thermometers were constructed following the design of Thorsson et al (2007) and comprised a hollow $38 \mathrm{~mm}$ matte gray acrylic sphere with a 12-bit temperature smart sensor fixed at the center. One globe thermometer was placed five meters east of the center of the shade cast by the tree canopy, ensuring that the globe thermometer was at least two meters away from the edge of the shade area. The second globe thermometer was placed so that the globe thermometer was within the center of the tree shade along the line between the center of the tree canopy and the center of the ground shade area. Both sensors were allowed an acclimation period of five minutes before starting a five minute period in which temperature readings were taken every five seconds. The readings were averaged over the five minute period to give a mean radiant temperature to improve the accuracy of the result as suggested by Thorsson et al.(2007).

\section{Surface Temperature Readings}

At each of the tree sample locations, two surface temperature readings were taken using a Fluke 572 infrared thermometer. The first reading was taken five meters east of the center of the shade cast by the tree canopy, ensuring that the surface temperature was taken at least two meters away from the edge of the shade area and that the area had never been in shade. The second reading was taken close to the western edge (trailing edge) of the tree canopy shade area to ensure that the surface had as much time in the shade as possible. In both cases, the sampled region was instantaneously shaded by the researcher during the reading to remove the calibration error that would have been caused by direct sunlight. Care was taken to ensure that the sample surface type was the same as the surface taken in full sun, and any asphalt where repairs had been made was avoided to ensure there was no difference in the sampled surface type. As no acclimatization period was necessary, surface readings were recorded within thirty seconds of each other.

\section{Analysis}

One-way ANOVA was used to assess whether there were significant differences between the tree species in their morphological characteristics and the area of shade they produced. The LAI was subjected to two-way ANOVA to additionally determine whether it was affected by the sample period. Air, globe, and surface temperatures in sun and shade were first tested using two-way ANOVA to investigate if tree shading and sample period had a significant effect on the temperatures. If shade had a significant effect on the temperatures, then the size of the effects produced by the different tree species were compared using one-way ANOVA with Tukey post hoc tests.

The relationships between the morphological features of trees and their effects of temperatures were also investigated using correlation analysis. All tests were conducted using SPSS V16 software and differences between groups were considered significant at $P<0.05$.

\section{RESULTS}

\section{Tree Morphology}

The five species had quite different overall morphology (Table 2 ), one-way ANOVA showing significant differences between the species in canopy height $\left(\mathrm{F}_{4,46}=6.280, P \leq 0.005\right)$, east and west canopy spread $\left(\mathrm{F}_{4,46}=8.311, P \leq 0.005\right)$ and canopy area $\left(\mathrm{F}_{4,46}\right.$ $=6.994, P \leq 0.005$ ) (Table 2). Post hoc analysis shows that of all the species, Prunus 'Umineko' had the tallest but narrowest 
canopy. In contrast, Malus 'Rudolph' had the shortest but widest canopy. Because the tallest trees also tended to be the narrowest, there were also significant differences in aspect ratio $\left(\mathrm{F}_{4,46}=24.91, P \leq 0.005\right)$, post hoc analysis showing that C. laevigata and Malus 'Rudolph' were significantly less elliptical than S. arnoldiana, P. calleryana, and Prunus 'Umineko' (Table 2).

\section{Leaf Area Index}

There were species differences in LAI (Figure 1a). Twoway ANOVA analysis showed that there were significant differences between species $\left(\mathrm{F}_{4,92}=7.48, P \leq 0.001\right)$ but not between the sample dates. Post hoc analysis showed that the $C$. laevigata and $P$. calleryana had significantly higher LAI than $S$. arnoldiana and Prunus 'Umineko'.

\section{Shade area}

The shade area cast by each species was not significantly different for either early summer $\left(\mathrm{F}_{4,46}=1.584, P=0.195\right)$ or mid-summer $\left(\mathrm{F}_{4,46}=1.366, \stackrel{4,}{P}=0.260\right)$ (Figure $1 \mathrm{~b}$ ).

\section{Air temperatures}

Mean air temperature was $22.1^{\circ} \mathrm{C}(\mathrm{StD} \pm 4.3)$ in sun and $22.1^{\circ} \mathrm{C}(\mathrm{StD} \pm 4.3)$ in tree shade in early summer and $21.9^{\circ} \mathrm{C}(\mathrm{StD} \pm 1.2)$ in sun and $22^{\circ} \mathrm{C}(\mathrm{StD} \pm 1.2)$ in shade in mid-summer. One-way ANOVA showed that there were no significant differences between sun and shade temperatures either in early summer $\left(\mathrm{F}_{1,100}=0.000\right.$, $P=0.987)$ or mid-summer $\left(\mathrm{F}_{1,100}=0.104, \stackrel{100}{P}=0.748\right)$. As shade had no effect upon the air temperature no further analysis of this measurement was carried out.

\section{Mean Radiant Temperatures}

The mean radiant temperatures were $27.7^{\circ} \mathrm{C}(\mathrm{StD} \pm 4.8)$ in sun and $23.9(\mathrm{StD} \pm 3.9)$ in shade in early summer and $28.3^{\circ} \mathrm{C}$ $(\mathrm{StD} \pm 1.9)$ in sun and $23.7^{\circ} \mathrm{C}(\mathrm{StD} \pm 1.1)$ in shade in midsummer, reductions of $3.8^{\circ} \mathrm{C}$ and $4.6^{\circ} \mathrm{C}$ due to shade respectively. One-way ANOVA showed that in both early summer $\left(\mathrm{F}_{1,100}=19.315, P \leq 0.005\right)$ and mid-summer $\left(\mathrm{F}_{1,100}=\right.$ 227.887, $P \leq 0.005)$ these differences were significant.

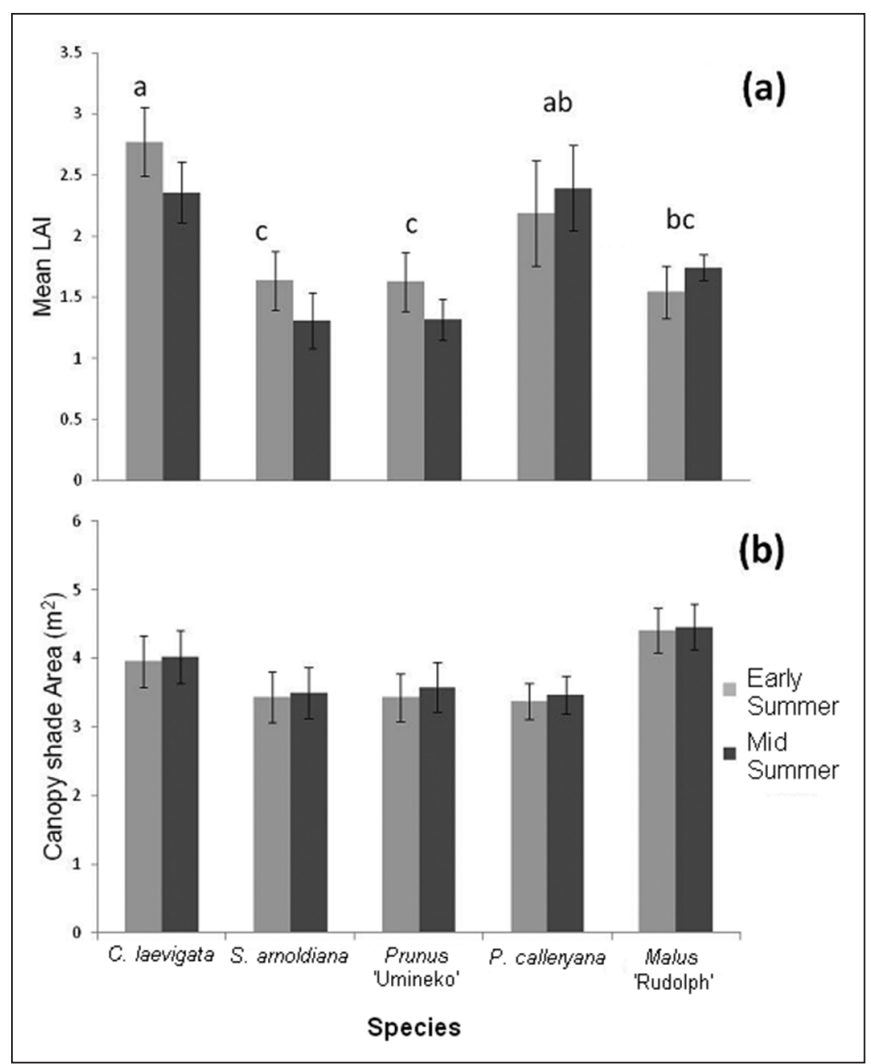

Figure 1. The mean LAI (a) and mean shade area (b) of five different street tree species in Manchester, UK, in early summer and midsummer 2011: C. laevigata $(n=12)$, $S$. arnoldiana $(n=10)$, Prunus 'Umineko' $(n=10)$, P. calleryana $(n=10)$, and Malus 'Rudolph' $(n=9)$. For LAI (a), species with the same letters are not significantly different from each other in both early and mid-summer; no significant differences were found for mean shade area (b) during either sample period.

The temperature reductions due to shading by the five tree species are shown in Figure 2a. One-way ANOVA showed that it was only in early summer (Figure 2a) that a significant difference between the species $\left(\mathrm{F}_{4,46}=2.613, P=0.047\right)$ could be found, Tukey post hoc analysis showing that $C$. laevigata reduced mean radiant temperatures significantly more than Prunus 'Umineko'.

Table 2. The mean canopy height, east/west canopy spread, canopy area and aspect ratio produced by five street tree species: C. laevigata $(n=12), S$. arnoldiana $(n=10)$, Prunus 'Umineko' $(n=10), P$. calleryana $(n=10)$, and Malus 'Rudolph' $(n=9)$. For each canopy attribute, species with the same letters are not significantly different from each other.

\begin{tabular}{|c|c|c|c|c|}
\hline Species & $\begin{array}{l}\text { Mean canopy } \\
\text { height }(\mathrm{m}) \text { (StErr) }\end{array}$ & $\begin{array}{l}\text { Mean east/west canopy } \\
\text { spread (m) (StErr) }\end{array}$ & $\begin{array}{l}\text { Mean canopy } \\
\text { area }\left(\mathrm{m}^{2}\right)(\text { StErr })\end{array}$ & $\begin{array}{l}\text { Aspect ratio } \\
\text { (StErr) }\end{array}$ \\
\hline C. laevigata & $\begin{array}{l}2.828 b c \\
(0.121)\end{array}$ & $\begin{array}{l}1.915 \mathrm{ab} \\
(0.100)\end{array}$ & $\begin{array}{l}3.030 \mathrm{ab} \\
(0.327)\end{array}$ & $\begin{array}{l}1.482 \mathrm{~b} \\
(0.072)\end{array}$ \\
\hline S. arnoldiana & $\begin{array}{l}3.456 \mathrm{abc} \\
(0.169)\end{array}$ & $\begin{array}{l}1.593 \mathrm{bc} \\
(0.097)\end{array}$ & $\begin{array}{l}2.062 b c \\
(0.238)\end{array}$ & $\begin{array}{l}2.185 b \\
(0.099)\end{array}$ \\
\hline Prunus 'Umineko' & $\begin{array}{l}3.881 \mathrm{a} \\
(0.337)\end{array}$ & $\begin{array}{l}1.489 \mathrm{c} \\
(0.063)\end{array}$ & $\begin{array}{l}1.914 \mathrm{c} \\
(0.188)\end{array}$ & $\begin{array}{l}2.486 b \\
(0.163)\end{array}$ \\
\hline P. calleryana & $\begin{array}{l}3.588 \mathrm{ab} \\
(0.152)\end{array}$ & $\begin{array}{l}1.554 \mathrm{c} \\
(0.076)\end{array}$ & $\begin{array}{l}1.983 c \\
(0.195)\end{array}$ & $\begin{array}{l}2.301 \mathrm{~b} \\
(0.091)\end{array}$ \\
\hline Malus 'Rudolph' & $\begin{array}{l}2.796 \mathrm{c} \\
(0.075)\end{array}$ & $\begin{array}{l}2.076 a \\
(0.083)\end{array}$ & $\begin{array}{l}3.377 \mathrm{a} \\
(0.246)\end{array}$ & $\begin{array}{l}1.360 \mathrm{a} \\
(0.033)\end{array}$ \\
\hline
\end{tabular}




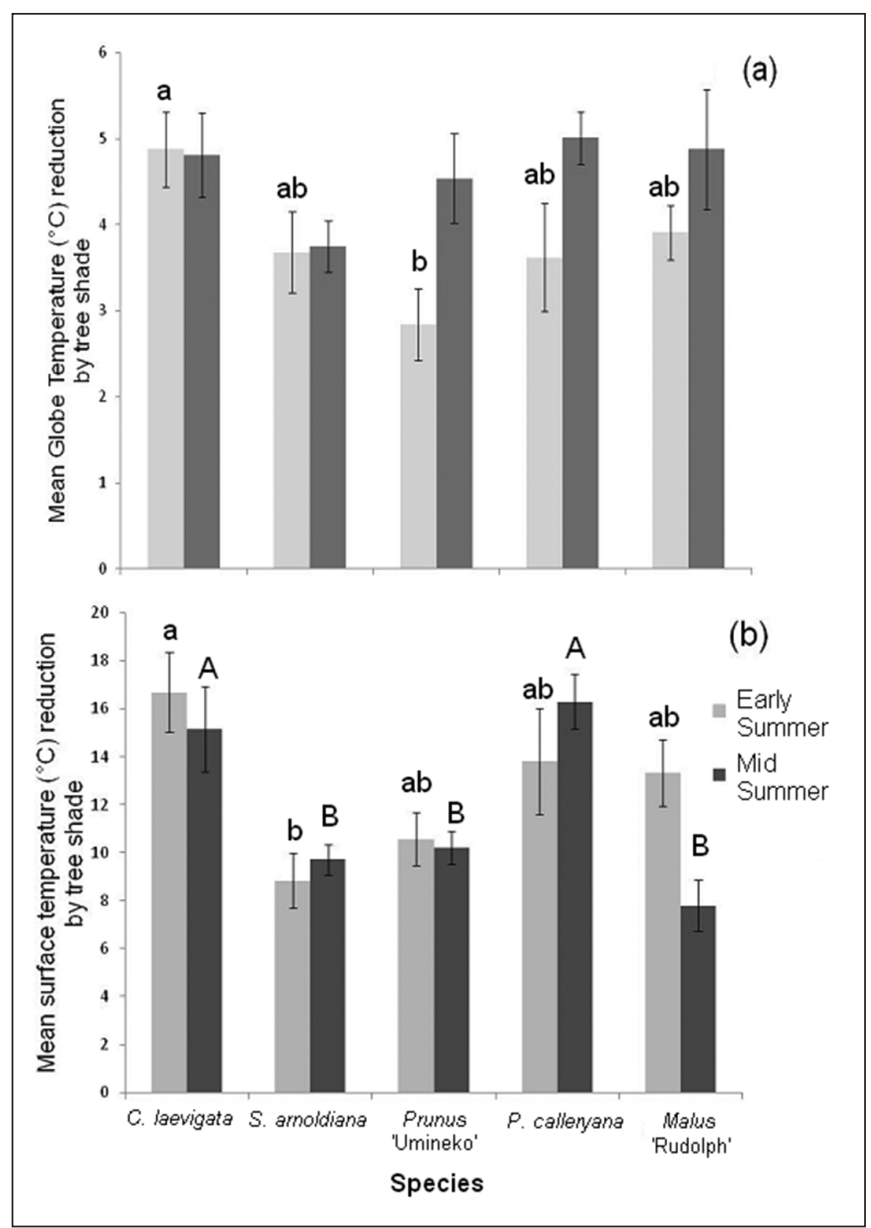

Figure 2. The mean reduction of mean radiant temperature (a) and surface temperature (b) in tree shade during early summer and mid-summer in Manchester, UK, below five different street tree species: $C$. laevigata $(n=12), S$. arnoldiana $(n=10)$, Prunus 'Umineko' ( $\mathrm{n}=10)$, . calleryana $(\mathrm{n}=10)$, and Malus 'Rudolph' $(n=9)$. Lowercase letters indicate significant differences in early summer while uppercase indicate significant differences in midsummer; species with the same letters are not significantly different from each other.

\section{Surface Temperatures}

The mean surface temperatures were $40.1^{\circ} \mathrm{C}(\mathrm{StD} \pm 6.6)$ in sun and $27.3^{\circ} \mathrm{C}(\mathrm{StD} \pm 4.5)$ in shade in early summer and $39.2^{\circ} \mathrm{C}(\mathrm{StD} \pm 4.4)$ in sun and $27.2^{\circ} \mathrm{C}(\mathrm{StD} \pm 3.38)$ in shade in mid-summer, reductions of $12.8^{\circ} \mathrm{C}$ and $12^{\circ} \mathrm{C}$ due to shade respectively. One-way ANOVA showed that in both early summer $\left(\mathrm{F}_{1,100}=129.440, P \leq 0.005\right)$ and mid-summer $\left(\mathrm{F}_{1,100}=\right.$ 239.583, $P \leq 0.005$ ), these differences were significant.

The temperature reductions due to shading by the five tree species are shown in Figure 2b. One-way ANOVA showed that there were significant differences between the species for both early summer $\left(\mathrm{F}_{4,46}=3.959, P=0.008\right)$ and mid-summer $\left(\mathrm{F}_{4,46}=136.779, \stackrel{P}{P}=0.005\right)$. Post-hoc analysis showed that during early summer, $C$. laevigata reduced surface temperature significantly more than $S$. arnoldiana, while in July, C. laevigata and P. calleryana both reduced the surface temperatures significantly more than Prunus 'Umineko', S. arnoldiana, and Malus 'Rudolph'.

\section{Relationship Between Morphology and Surface Temperature}

The morphology of individual trees also affected their performance at reducing surface temperature. There was a significant positive correlation between LAI and surface temperature reduction in both early summer $\left(\mathrm{r}_{\mathrm{s}(49)}=0.735, P \leq 0.005\right)$ and mid-summer $\left(\mathrm{r}_{\mathrm{s}(49)}=0.549, P \leq 0.005\right)$. Trees with higher LAI reduced surface temperatures by a greater amount than those with lower values. There was also a significant negative correlation between aspect ratio and surface temperature in early summer $\left(\mathrm{r}_{\mathrm{s}(49)}=-0.313\right.$, $P=0.025)$ but not mid-summer $\left(\mathrm{r}_{\mathrm{s}(49)}=0.045, P=0.745\right)$. Trees with more elliptical canopies reduced surface temperatures less.

\section{DISCUSSION}

\section{Experimental Limitations}

Unfortunately, this research was limited to young trees of small species because they were the only ones for which the study authors had adequate planting data. Because of the lack of historical records for trees in Manchester it was not possible to investigate the shading benefits of larger, more mature trees, which might be expected to have greater effects. It must be remembered, also, that species must also be chosen so that they are capable coping with the harsh growing conditions found in urban areas, which are only likely to get worse with future climate change. Because it was carried out on real streets, the research presented here necessarily has limitations in experimental design and sampling size. In an ideal experiment, trees would be randomly placed within identical streets with identical surfaces and growing conditions. Fortunately, though the trees were not evenly spread, the different streets had similar morphology and asphalt paving, and they were located within a small area, so the soil conditions were likely to be similar. Neither was it possible to continually monitor the trees because of problems with vandalism, and so the research was limited to two visits during periods of warm, sunny weather, when the shading effects of the trees was likely at its maximum. The poor summer meant that even during these visits conditions were not ideal, but despite the relatively low air temperatures, the visits should have recorded the maximum effects of shading because on the sampling days the trees were being heated by full sun. Despite the fact that sampling was carried out only twice, the large number of trees sampled meant that researchers obtained reliable and statistically analyzable data on both occasions, and despite its limitations, the research showed clear trends in the shading effects of street trees that can be extrapolated to provide recommendations about how to maximize tree shade benefits.

\section{Tree Morphology and Shade}

The sampled tree species showed significant differences in their canopy size and shape, but these differences did not result in significant differences between the shade areas produced by the tree canopies. This was no doubt because the taller trees, such as Prunus 'Umineko' had narrower canopies, while the shorter trees, such as C. laevigata and Malus 'Rudolph' had wider canopies. This difference in shape is quantified by the widely differing aspect ratios of the canopies of the five species, which ranged from 1.5 to 2.5. The tree species with most elliptical canopies, 
and hence higher aspect ratios, cast more shade relative to their canopy area because of the inclination of the sun. The shade areas cast by the trees were around $50 \%$ greater than canopy area for S. arnoldiana, P. calleryana and Prunus 'Umineko', but only around $30 \%$ greater for C. laevigata and Malus 'Rudolph'. Therefore the effect of canopy diameter and height cancelled each other out, at least at midday in the summer. It is likely, however, that in the morning and evening, and earlier and later in the year when the sun is at a lower angle, the taller, thinner trees will cast greater shade than the shorter, wider ones. It is clear, therefore, that the area of shade cast by street trees is much larger than their canopy areas, and this will be particularly true for tall, thin trees and when the sun is at a lower angle.

\section{Air Temperatures}

Unlike the many other studies reviewed by Bowler et al. (2010), tree shade did not have a significant impact upon the local air temperatures below the tree canopies. To some extent, this may have been due to the thermometers, which have a measurement error of around $0.2^{\circ} \mathrm{C}$. However, the effect was clearly far less than the $1^{\circ} \mathrm{C}$ average effect described by Bowler et al. (2010). This is probably because the tree canopies were so small and the air was not perfectly still. Warm air would have readily been advected into the area of shade beneath the trees' canopy.

\section{Mean Radiant Temperatures}

Tree shade reduced mean radiant temperatures by around $4^{\circ} \mathrm{C}$ during both measurement periods, but only in early summer were there any significant differences between the species. It is likely that the difference between the species in early summer is because $C$. laevigata reached its maximum leaf density earlier than the other species and so reduced solar radiation more in its shade than the other species, which came fully into leaf later. Once all the species were in full leaf during July, the earlier differences between the species were not apparent.

The reductions in mean radiant temperature found in this investigation, ranging from $3.8^{\circ} \mathrm{C}$ to $5^{\circ} \mathrm{C}$, were somewhat lower than the maximum reductions of $5^{\circ} \mathrm{C}-7^{\circ} \mathrm{C}$ researchers previously found for areas in permanent tree shade (Armson et al. 2012). This is probably because of two reasons. First, the air temperatures in this survey were not as high as those recorded in the earlier study, with mean air temperatures of $22^{\circ} \mathrm{C}$ rather than $28^{\circ} \mathrm{C}$. Second, the large trees and banks of trees in the earlier study probably cast denser shade. Nevertheless, the mean $4^{\circ} \mathrm{C}$ temperature reduction is large and would be particularly important to human thermal comfort, as it represents the reduction of perceived heat a person would feel in tree shade. Mean radiant temperatures are a primary determinant of the physiological equivalent temperature (PET) which is used to assess human thermal comfort in a specific area (Matzarakis et al. 1999). Determining human thermal comfort is a complex and problematic process, however, and there are other indices as well as PET. Calculating PET involves measuring received radiation in three planes, as well as the air temperature, relative humidity, wind speed, and cloud cover. Matzarakis et al. (1999) investigated comfort levels at various PET levels and found that people were most comfortable when PET was between $18^{\circ} \mathrm{C}$ and $23^{\circ} \mathrm{C}$, with slight heat stress beginning above this level and increasing as PET increased further. In this survey, tree shade reduced mean radiant temperatures from around $28^{\circ} \mathrm{C}$ to values below $24^{\circ} \mathrm{C}$. These temperature are almost within the comfort level of Matzarakis et al. (1999) and below the $24.5^{\circ} \mathrm{C}$ discomfort level for air temperature suggested by Wilson et al. (2008). The tree shade would be enough to produce cool "refuge" areas on hot days.

\section{Surface Temperatures}

Tree shade reduced surface temperatures by $12^{\circ} \mathrm{C}$, on average, and there were significant differences between the species. The greater cooling provided by $C$. laevigata and $P$. calleryana are probably related to the high LAI of these species, which consequently would produce denser shade, reducing the incident solar radiation on the surface. This suggestion is backed up by the correlation analysis, which showed that trees with a higher LAI provide greater surface cooling than trees with a low LAI. Planting trees with a higher LAI should therefore contribute more to this aspect of reducing the urban heat island.

Once again, the reductions in surface temperature, around $12^{\circ} \mathrm{C}$, caused by these small street trees, was smaller than the maximum temperature reductions caused by permanent tree shading of around $20^{\circ} \mathrm{C}$ (Armson et al. 2012). The difference is partly due to the lighter shade these small trees cast, but another important effect is that the trees only cast shade on a specific surface point for a period of 1-2 hours. Tall, slender trees will cast shade for a particularly short time, meaning it was no surprise that temperature reductions were negatively correlated with canopy aspect ratio, at least in early summer.

Nevertheless, whatever the canopy form, it is clear that the shade cast by street trees can contribute to significant reductions in surface temperatures, at least locally, and this will have the effect of reducing heat storage in the paved surface. Combined with the evapotranspirational cooling the trees produce, this should help ameliorate the urban heat island effect. It is hoped that results such as these can be incorporated into physical models of the urban environment to help quantify the regional thermal benefits of street trees (Stone and Rogers 2001; Stone and Norman 2006; Chen and Wong 2009).

\section{CONCLUSION}

The results of this study have shown that although the shade cast by small street trees is not large enough to cause local reductions in air temperature it can have significant meteorological benefits. First, shade significantly reduces mean radiant temperatures and can create "refuge" areas for people on hot days. Second, shade can also reduce surface temperatures, which will help reduce storage of heat in hard surfaces and so have a regional effect in reducing the urban heat island effect. The areas of shade that street trees provide are also much greater than their actual canopy area-by 30\%-50\%, even at midday - so their influence, unlike that of areas of grass, extends outside their canopy. Although the study authors did not find any difference in the area of shade cast between the species, researchers did find that species with a higher LAI, such as $C$. laevigata and $P$. calleryana, do reduce surface temperatures more because they cast a denser shade. Trees with a lower aspect ratio also reduce surface temperatures more because they shade a specific point on the ground for longer. This suggests that to optimize the benefits of street trees it is best to plant trees that have as broad and dense a canopy as possible. 
Acknowledgments. This study was carried out while David Armson was in receipt of a NERC studentship and Mohammad Asrafur Rahman was in receipt of a Sustainable Consumption Institute, University of Manchester studentship, with the Red Rose Forest and INTERREG IVB (as part of the VALUE project) as CASE partners.

\section{LITERATURE CITED}

Akbari, H., D.M. Kurn, S. Bretz, and J.W. Hanford. 1997. Peak power and cooling energy savings of shade trees. Energy \& Buildings 25:139148. Akbari, H., M. Pomerantz, and H. Taha. 2001. Cool surfaces and shade trees to reduce energy use and improve air quality in urban areas. Solar Energy 70:295-310.

Armson, D., P. Stringer, and A.R. Ennos. 2012. The effect of tree shade and grass on surface and globe temperatures in an urban area. Urban Forestry \& Urban Greening 11(3):245-255.

Bowler, D.E., L. Buyung-Ali, T.M. Knight, and A.S. Pullin. 2010. Urban greening to cool towns and cities: A systematic review of the empirical evidence. Landscape \& Urban Planning 97(3):147-155.

Britt, C., and M. Johnston. 2008, Trees in towns II. I: New survey of urban trees in England and their condition and management. London: Communities and Local Government.

Chen, Y., and N.H. Wong. 2009. Thermal impact of strategic landscape in cities: A review. Advances in Building Energy Research 3(1):237-260.

Heisler, G.M. 1986a. Effects of individual trees on the solar radiation climate of small buildings. Urban Ecology 9:337-359.

Heisler, G.M. 1986b. Energy savings with trees. Journal of Arboriculture 12(5):113-125.

Kjelgren, R., and T. Montague. 1998. Urban tree transpiration over turf and asphalt surfaces. Atmospheric Environment 32:35-41.

Leuzinger, S., R. Vogt, and C. Körner. 2010. Tree surface temperature in an urban environment. Agriculture and Forest Meteorology 150(1):56-62.

Matzarakis, A., F. Rutz, and H. Mayer. 2007. Modeling radiation fluxes in simple and complex environments: Application of the RayMan model. International Journal of Biometerology 51(4):323-334.

Matzarakis, A., H. Mayer, and M.G. Iziomon. 1999. Applications of a universal thermal index: Physiological equivalent temperature. International Journal of Biometerology 43:76-84.

Miller, D. 1980. The two-dimensional energy budget of a forest edge with field measurements at a forest-parking lot interface. Agricultural meteorology 22(1):53-78.

Monteith, J.L., and M.H. Unsworth. 1990. Principles of Environmental Physics. New York: Edward Arnold.

Oke, T.R., 1978. Boundary Layer Climates. London: Methuen.

Pataki, D.E., H.R. McCarthy, E. Litvak, and S. Pincetl. 2011. Transpiration of urban forests in the Los Angeles metropolitan area. Ecological Applications 21(3):661-667.

Pauleit, S. 2003. Urban street tree plantings: Identifying the key requirements. Proceedings of the Institution of Civil Engineers. Municipal Engineer 30:80-91.

Pauleit, S., and F. Duhme. 2000. GIS assessment of Munich's urban forest structure for urban planning. Journal of Arboriculture 26(3):133-141.

Peters, E.B., R.V. Hiller, and J.P. McFadden. 2011. Seasonal contributions of vegetation types to suburban evapotranspiration. Journal of Geophysical Research 116:16.

Rahman, M.A., J.G. Smith, P. Stringer, and A.R. Ennos. 2011. Effect of rooting conditions on the growth and cooling ability of Pyrus calleryana. Urban Forestry \& Urban Greening 10(3):185-192.
Scott, K.L., J.R. Simpson, and E.G. McPherson. 1999. Effects of tree cover on parking lot microclimate and vehicle emissions. Journal of Arboriculture 25(3):129-142.

Shashua-Bar, L., and M.E. Hoffman. 2000. Vegetation as a climatic component in the design of an urban street: An empirical model for predicting the cooling effect of urban green areas with trees. Energy and Buildings 31:221-235.

Smith, C.L., A. Webb, G.J. Levermore, S.J. Lindley, and K. Beswick. 2011. Fine-scale spatial temperature patterns across a UK conurbation. Climate Change 109(2-4):269-286.

Stone, B., and J.M. Norman. 2006. Land use planning and surface heat island formation: A parcel-based radiation flux approach. Atmospheric Environment 40:3561-3573.

Stone, B., and M.O. Rodgers. 2001. Urban form and thermal efficiency: How the design of cities influences the urban heat island effect. Journal of the American Planning Association 67(2):186-198.

Streiling, S., and A. Matzarakis. 2003. Influence of single and small clusters of trees in the bioclimate of a city: A case study. Journal of Arboriculture 29:309-316

Thorsson, S., F. Lindberg, I. Eliasson, and B. Holmer. 2007. Different methods for estimating the mean radiant temperature in an outdoor urban setting. International Journal of Climatology 27(14):1983-1993.

Wilson, E., F. Nicol, L. Nanayakkara, and A. Ueberjahn-Trita. 2008. Public urban open space and human thermal comfort: The implications of alternative climate change and socio-economic scenarios. Journal of Environmental Policy \& Planning 10(1):31-45.

Wong, N.H., D.K.W. Cheong, H. Yan, J. Soh, C.L. Ong, and A. Sia. 2003. The effects of rooftop garden on energy consumption of a commercial building in Singapore. Energy \& Buildings 35:353-364.

David Armson, Ph.D. (corresponding author)

Faculty of Life Sciences

University of Manchester

Manchester, M13 9PT, UK

davearmson@gmail.com

Mohammad Asrafur Rahman

Faculty of Life Sciences

University of Manchester

Manchester, M13 9PT, UK.

Mohammad.Rahman-3@postgrad.manchester.ac.uk

Anthony Roland Ennos, Ph.D.

Faculty of Life Sciences

University of Manchester

Manchester, M13 9PT, UK.

roland.ennos@manchester.ac.uk 
Résumé. L'un des bénéfices majeurs des arbres urbains est l'ombrage qu'ils produisent lors des jours ensoleillés; ceci diminue la chaleur emmagasinée dans les surfaces minérales ainsi que la quantité de chaleur que doit supporter les gens, ce qui accroît leur degré de confort. Cette étude compare l'efficacité de l'ombrage produit par cinq espèces d'arbres de rues à faible déploiement au sein du paysage urbain de Manchester au Royaume-Uni. La surface d'ombrage produite par chacun des arbres durant le début et le milieu de l'été 2012 a été calculée à partir de mesures morphologiques telles que la hauteur de la canopée, sa largeur et sa forme. L'effet de l'ombrage sur les températures de l'air, de la moyenne de radiation et en surface a aussi été comparé et relié à l'index de surface foliaire de la canopée. On a découvert que l'ombrage d'un arbre réduisait les moyennes de température radiante de $4^{\circ} \mathrm{C}$ en moyenne, et ce sans que l'espèce ou l'index de surface foliaire ait une influence particulière. L'ombrage des arbres diminuait les températures à la surface d'une moyenne de $12^{\circ} \mathrm{C}$; l'index de surface foliaire et l'espèce avaient une influence à ce chapitre. Les espèces d'arbres avec un index de surface foliaire plus élevé, soit le Crataegus laevigata et le Pyrus calleryana, donnaient plus de refroidissement que les autres espèces et la réduction de température à la surface était corrélée positivement avec l'index de surface foliaire. Cette étude a démontré que les arbres sont utiles pour améliorer à la fois le confort thermique des gens et diminuer les températures en surface dans les zones urbaines, et que la sélection d'arbres avec un index de surface foliaire élevé pouvait maximiser les bénéfices obtenus.

Zusammenfassung. Ein großer Vorteil von urbanen Bäumen ist der Schatten, den sie an sonnigen Tagen spenden. Das reduziert die gespeicherte Wärme in Gebäudeoberflächen und reduziert die Hitzebelastung bei den Menschen, was ihr Wohlbefinden steigert. Diese Studie vergleicht die Schattenwirkung von fünf kleinen Straßenbaumarten in der urbanen Landschaft von Manchester, Großbritannien. Die von jedem Baum während des Früh- und Mittelsommers 2012 produzierte Schattenfläche wurde anhand verschiedener morphologischer Parameter wie Kronenhöhe, -breite und Verhältnis berechnet. Die Auswirkungen der Schattenbäume auf Luft, durchschnittlichem Radiant und Oberflächen- temperaturen wurden auch verglichen und mit dem Blattflächenindex (LAI) in Beziehung gesetzt. Der Baumschatten reduzierte die Oberflächentemperatur durchschnittlich um $12^{\circ} \mathrm{C}$ und sowohl die Baumart, wie auch der LAI hatten einen signifikanten Effekt. Baumarten mit höherem LAI, Crataegus laevigata und Pyrus calleryana, lieferten deutlich mehr Kühlung als die anderen Arten und die Oberflächentemperaturreduzierung war positiv mit dem LAI korreliert. Die Studie hat gezeigt, dass Bäume zur Verbesserung menschlichen Wohlbefindens und zur Reduzierung von Oberflächentemperaturen in urbanen Bereichen beitragen und dass eine Auswahl von Bäume mit höherem LAI diese Vorteile noch maximieren können.

Resumen. Una ventaja importante de los árboles urbanos es la sombra que proporcionan en los días soleados, lo que reduce el calor almacenado en las superficies construidas y reduce la carga de calor en las personas, aumentando su bienestar. Este estudio comparó la eficacia de la sombra de cinco especies de árboles pequeños en el paisaje urbano de Manchester, Reino Unido. La zona de sombra producida por cada árbol a principios de 2012 y mediados del verano se calculó a partir de las mediciones morfológicas, como la altura, anchura y relación con el dosel. El efecto de la sombra de un árbol en el aire, temperaturas medias radiantes y superficiales fue también comparado y relacionado con el índice de área foliar (IAF) de la cobertura. Se encontró que la sombra de los árboles reduce las temperaturas medias radiantes en un promedio de $4^{\circ} \mathrm{C}$, aunque ninguna especie arbórea ni IAF tuvieron un efecto significativo. La sombra del árbol reduce las temperaturas superficiales en un promedio de $12^{\circ} \mathrm{C}$, y las especies de árboles y los IAF tuvieron efectos significativos. Las especies de árboles con mayor IAF, Crataegus laevigata y Pyrus calleryana, proporcionaron significativamente mayor enfriamiento que las otras especies, y la reducción de temperatura superficial se correlacionó positivamente con la IAF. Este estudio ha demostrado que los árboles son útiles en la mejora del confort térmico humano y la reducción de las temperaturas superficiales en las zonas urbanas, y que la selección de especies de árboles con alto IAF puede maximizar los beneficios que ellos proporcionan. 